\title{
The Impact of Field Dependence/Independence Cognitive Styles and Gender Differences on Lexical Knowledge: The Case of Iranian Academic EFL Learners
}

\author{
Seyyedeh Mitra Niroomand \\ Department of English, Abadeh Branch, Islamic Azad University, Abadeh, Iran \\ Mohammad Rostampour \\ Department of English, Abadeh Branch, Islamic Azad University, Abadeh, Iran
}

\begin{abstract}
Most of the research which has investigated the relationship between effective learners' variables and language proficiency allows the researcher to quantify the strength of the relationship. The scope of this paper limited to examining the role of field dependence/independence cognitive styles and gender differences on EFL learners' lexical knowledge. To attain the goals of the research, a number of EFL learners sat through the Vocabulary Size Test (VST) as well as the Group Embedded Figures Test (GEFT). The findings of the study indicate the need for caution when concluding that cognitive styles of field dependence/independence affect lexical knowledge in the absence of tests for possible interactions between FD/FI and other variables, including gender differences that may influence vocabulary knowledge. By the same token, understanding the effective role of students' cognitive aspects and gender will enable teachers and researchers to design appropriate materials and activities to help students enhance their lexical competence.
\end{abstract}

Index Terms - field dependence/independence cognitive styles, gender differences, lexical knowledge, EFL Learners

\section{INTRODUCTION}

A number of variables are found to be affecting EFL proficiency and, consequently the foreign language acquisition process. So, it will become increasingly difficult to typify individuals and to classify groups of individuals together, since each person appears to be a unique complex of variables. In the same vein, some researchers have attempted to isolate particular learner variables which might enhance or hinder progress in learning a foreign or second language (Chapelle \& Roberts, 1986; Reid, 1987; Wenden \& Rubin, 1987; O’Malley \& Chamot, 1990; Oxford, 1990; Skehan, 1991). As cited in Dreyer and Vander Walt (1994), various research identified a number of variables that account for some of the differences in how students learn, including attitude and motivation (Gardner \& Lambert, 1972; Gardner \& Smythe, 1975; Gardner, Smythe, \& Brunet, 1977), personality type/traits (Chastain, 1975; Guiora et al., 1975; Brodkey \& Shore, 1976; Busch, 1982), learning styles (especially the field dependence/independence distinction) (Witkin et al., 1977a, 1977b; Birckbichler \& Omaggio, 1978; Hosenfeld, 1979; Hansen \& Stansfield, 1981, 1982; Chapelle \& Roberts, 1986; Ried, 1987), and language learning strategies (Bialystok \& Fröhlich, 1978; Bialystok, 1981; Wenden, 1983, 1986a, 1986b; O'Malley, Chamot, Stewner-Manzanares, Kupper, \& Russo, 1985a, 1985b; Wenden \& Rubin, 1987; Oxford, 1989; O'Malley \& Chamot, 1990; Oxford, 1990). By the same token, in recent years there has been an increasing awareness of the necessity in second or foreign language research and teaching to investigate cognitive aspects and gender differences that have undeniable effects on language learning and teaching.

Cognitive or learning style has been found to be one of the important factors from among students' personal attributes that can affect learning processes and learners' performance. Cognitive styles are the attributes that exist within learners, affecting the way they function intellectually. Accordingly, Brown (1994) stats that "the way we learn things in general, and the particular attacks we make on a problem seems to hinge on a rather amorphous link between personality and cognition; this link is referred to as cognitive style" (p. 104). Furthermore, field dependence/field independence has been one of the most widely studied with regard to its educational implications among the various dimensions of cognitive style. Hence, Hansen-Strain (1984) studied field dependence/independence as a cognitive style in terms of age, gender differences, and culture.

Concerning second or foreign language acquisition, particular attention has been given to learners' approaches based on gender differences to a vocabulary task, since vocabulary plays a significant role in achieving high results in second or foreign language learning, and in promoting an individual's ability to function well in many spheres of life. In other words, vocabulary has long been considered as a strong determinant of reading achievement. "It is clear that a large and 
rich vocabulary is the hallmark of an educated individual. Indeed, a large vocabulary repertoire facilitates becoming an educated person to the extent that vocabulary knowledge is strongly related to reading proficiency in particular and school achievement in general" (Beck, Mckeown \& Kucan, 2002, p. 1). Accordingly, Kraft \& Nichel (1995) in their investigation proved female learners' advantages on measures of verbal fluency, vocabulary and quality of speech.

Considering the aforementioned issues, learning vocabulary is considered as one of the first steps of learning a second or foreign language. According to Read (2002), "vocabulary, along with grammar and reading comprehension was the aspect of language that was most commonly included in new objective tests" (p. 304). Moreover, concerning the importance of vocabulary and its role in second language learning, Seal (as cited in Celce-Murcia,1991) asserts that "words are perceived as the building blocks upon which knowledge of the second language can be built" (p. 296). To put into simple words, words are considered as the basic building blocks of an utterance, units of meaning from which larger structures such as sentences, paragraphs, and whole texts are formed. Also, having adequate knowledge of vocabulary is considered as the most important factor in communication (Roever, 2001). Regarding the importance of lexical competence, Sener (2009) restated Wilkins' (1972) famous saying that without grammar, very little can be conveyed, without vocabulary nothing can be conveyed.

\section{LITERATURE REVIEW}

There is some evidence to support the impact of socioeconomic status and authoritarian societies on field dependence/independence cognitive styles. In a study conducted at university of Barcelona by Forns-Santacana, Amador-Campos, \& Roig-Lopez (1993), the students of different economic backgrounds took part in the GEFT. For finding the simple shapes embedded in the complex set, skills of perceptual reconstruction are needed. The results showed that students of higher economic classes performed better on GEFT, which proved that they are more developed in perceptual reconstruction skills and more field-independent. In addition, the gender variable produced differences only in the FD/FI variable, where boys scored higher than girls. Furthermore, Brown (1994), in his study, claimed that authoritarian societies which are highly socialized and use strict laws tend to raise more field dependent people while democratic and industrialized societies with a competitive nature and freer norms tend to produce more field independent people.

Witkin and Goodenough (1981) stated that the way parents treat their children influences the degree of being fielddependent or field-independent. The studies of child rearing showed that field independence tendencies result from child rearing methods or norms that emphasize gaining independence from parental control. They claimed that when there is a strong emphasis on the obedience to parental authority, and external control of impulses, the child will likely become field-dependent. When the child is encouraged to function autonomously and be independent, he or she will become relatively field independent.

Field dependent and field independent individuals are interested in different fields of study. Witkin et al. (1977) reported that more field dependent students are interested in social sciences while field independent students like mathematics and science. Saurenman (1980) studied high/low achieving students in terms of their FD/FI cognitive style. It was concluded that high achieving learners tend to be more field independent, more creative in divergent production tasks, and more interested in academic achievement. Besides, Mrosla (1983) studied the difference between low and high achieving mathematics learners. She found that high achieving mathematics students were more FI than low achieving mathematics students.

Chapelle and Roberts (1986) argued that a good language learner is one who is field independent and tolerant of ambiguity. The results of their investigations confirmed this hypothesis that FI and AT are the characteristics of a good language learner and predict success in language learning. Conversely, Brown (1987) and Carter (1988) found that field dependence was more advantageous for language learning.

Some studies have attempted to find an evidence for a relationship between field dependence/independence cognitive styles and second language acquisition. A study was done in Canada with English-speaking students learning French (Tinajero \& Paramo, 1998). The results of the study showed a significant positive correlation with achievement on French reading, listening, writing, and grammar tests. In addition, they indicated that field independence cognitive style was a significant predictor of second language proficiency in French.

Padilla-Falto (1996) attempted to find the effects of instruction and field dependence/independence cognitive styles on the acquisition of Spanish prepositions (i.e. por and para) in advanced-learners of Spanish as a second language. The first hypothesis that field-dependent students learn the prepositions better was supported, but second hypothesis that FD learners will perform better in a grammar-based, teacher-centered classroom environment was not supported.

The effects of field dependence/independence cognitive styles on speaking, listening, reading, and writing skills have been investigated in some studies. Hwang (1997) found a significant positive correlation between listening comprehension and field independence.

Genesee and Hamayan (1980, as cited in Bialystok, 1992) found that FI was correlated with written language proficiency and listening comprehension, but not with oral production for younger children. In other words, they studied first grade English speaking students in a French immersion program in Canada. They reported positive and significant correlation between FI and French listening comprehension skills and general achievement in French. 
Drane, Halpin, von Eschenbach, and Worden (1989, as cited in Eftekhar Hosseini, 2005) investigated the relationship between field dependence/independence cognitive styles, reading proficiency, and gender on a group of female and male second graders. They found that there were no significant gender differences in reading comprehension scores. However, FI students were more proficient readers than FD ones.

Rezaeian (2012) studied the possible relationship between field dependence/independence as a cognitive style and foreign language proficiency considering some other variables as sex and age in Iranian language learners. The research sample included 148 students (70 males and 78 females) studying at Level Ten at the Iran Language Institute. The other 146 students including 68 males and 78 females were university students at Shiraz University. The ILI students were at the age cohort of 15-17, and university students were at the age cohort of 22-26. They were given the Group Embedded Figures Test to determine the cognitive style, and Oxford Placement Test to measure the proficiency of the students. The results indicated that field dependence/independence was a significant factor affecting the performance of the students on the proficiency test. Furthermore, age and sex were found to affect the degree of field dependence/independence in Iranian language learners.

In their study, Rezaee and Farahian (2012) revealed a clear picture of field dependent and independent learners. For this purpose, their case study reported a university freshman who was observed for three months in a grammar class at a university. Based on the pieces of evidence obtained through making use of five instruments, observation, Grammar Test, interview with subject, private classroom interactions, and Embedded Figures Test, it was revealed that the student was a field-independent learner. While interviewing with the learner, it was also revealed that years of learning grammar in academic contexts did not result in the subject's skill in composing sentences. They found that despite the view that field independent learners profit more de-contextualized analytic approaches and formal context (SavilleTroike, 2006), such an approach may not help the learners. The result of this study supported the hypothesis that "FI person plays a major role in the acquisition of linguistic competence but not communicative competence" (Hansen \& Stansfield, 1981, p. 353). It implies that they learn the language components well, but they might have problem using it in the context globally.

There is an evidence to support the existence of positive and credible relationship between field dependence/independence cognitive styles and vocabulary knowledge (Rostampour and Niroomand, 2014). In a study conducted among Iranian male and female undergraduate EFL learners, a vocabulary size test was administered to divide the students into three groups of high, mid, and low in terms of their vocabulary level. Then the participants' cognitive styles were measured through the Group Embedded Figures Test (GEFT). The findings of the study indicated that field dependence/independence cognitive styles had a significant correlation with vocabulary knowledge in the high, mid groups.

As this review has demonstrated, there are a lot of interests on cognitive styles of field dependence/independence. All in all, considering the aforementioned studies, the following research questions are posed:

Q1. Do field dependence/independence cognitive styles influence the EFL learners Vocabulary knowledge?

Q2. Does the interaction of gender affect these learners' vocabulary knowledge?

\section{METHOD}

\section{A. Participants}

The current research was administered at Islamic Azad University, Shiraz branch. The participants majored in English language teaching for their bachelor's degree. Out of the entire sample (82 male and female students) only forty-four females and fifteen males comprised the study participants. They were at the age cohort of 21-29.

\section{B. Instruments}

-The Vocabulary Size Test (VST) was developed by Nation (2007) to gauge students' receptive vocabulary size from the first 1000 to the fourteenth 1000-words families of English words. In other words, this test is used to determine the students' vocabulary levels. It was written in the form of multiple-choice items. Test-takers are required to have a fairly well-developed idea of the meaning of the words to correctly answer the items because the correct answer and the distractors frequently share elements of meaning.

-The Group Embedded Figures Test (GEFT) used as a tool for measuring field dependence/independence of the testtakers was developed by Witkin, Raskin, Oltman, and Karp (1971). They reported a Spearman-Brown reliability coefficient of 0.82 for their instrument. The GEFT instrument contains complex figures within which simple geometric figures are embedded. The simple forms are present in the complex figures in the same size, the same proportions, and in the same direction as when they appear alone. The participants are supported to figure out the simple geometric shapes and to trace them in pencil directly over the lines of the complex figures. Field-independent participants can easily locate a large number of simple figures while field-dependent participants are able to locate just a small number of them. As in particular, the Group Embedded Figures Test consists of three sections with 25 complex figures. The first section includes seven simple figures and is given as a practice. The time allocated for this section is 2 minutes. Each section, two and three, includes nine complex pictures and the time allowed for each is 5 minutes. So, the participants are asked to find 18 simple figures just within 10 minutes. The total grade of the test-taker is scored by the number of the simple pictures correctly figured out in the second and third sections. One point is given to every correct 
response, and the participants are not given any points for locating the simple shapes in the first section. Therefore, the scores of GEFT can range from 0 to 18 .

\section{Procedures}

The study was carried out at the end of two educational sessions, with the administration of two tests of Vocabulary Size which determines the students' level of vocabulary knowledge, and Group Embedded Figures which determines the participants' degree of field dependence/independence cognitive styles. Before administrating the GEFT in allocated time, a brief explanation was given to the participants about the way they can easily figure out the simple geometric shapes and trace them in pencil directly over the lines of the complex figures. After calculating the students' vocabulary breadth scores were out of 140 and GEFT scores were out of 18, a two-way ANOVA was run so as to demonstrate the effects of independent variables (the FDI cognitive styles and gender differences) on dependent variable (vocabulary knowledge).

\section{RESUlTS \& DiSCUSSION}

Cognitive or learning style has been considered one of the important factors from among students' personal attributes that can affect learning processes and learners' performance. Accordingly, the study investigated whether or not the cognitive styles of field dependence/independence, gender, and the interaction of them could be affective on EFL learners' vocabulary knowledge. In other words, it was hypothesized that field dependence/independence cognitive styles do not influence the EFL learners' lexical knowledge. In addition, the interaction of gender does not affect these learners' knowledge of vocabulary.

Based on the students' raw scores on GEFT, they were classified into three groups of Field-Dependents (FD), FieldIntermediates (FInt), and Field-Independents (FI). In this regard, the participants who scored 7 or higher were considered as FI, and those who scored 5 or lower were considered as FD. Field intermediate scores were between 5 and 7. A summary of demographic data by cognitive styles and gender differences is reported in Table I.

TABLE I.

DEMOGRAPHIC DATA FOR COGNITIVE STYLES AND GENDER DIFFERENCES

\begin{tabular}{llll}
\hline Gender Differences & Field Dependent & Field Intermediate & Field Independent \\
\hline Males & 7 & 1 & 7 \\
Females & 23 & 2 & 19 \\
Total & 30 & 3 & 26 \\
\hline
\end{tabular}

As it can be observed, Table I presents the demographic information about the study independent variables. Moreover, in order to demonstrate the effects of independent variables (the FDI cognitive styles and gender differences) on dependent variable (vocabulary knowledge), a two-way ANOVA was run. Table II provides the results of the twoway analysis of variance.

TABLE II.

RESULTS OF TWO-WAY ANOVA

DEPENDENT VARIABLE: VOCABULARY KNOWLEDGE

\begin{tabular}{llllll}
\hline Source & $\begin{array}{l}\text { Type III Sum of } \\
\text { Squares }\end{array}$ & Df & Mean Square & F & Sig. \\
\hline Corrected Model & $6343.385 \mathrm{a}$ & 5 & 1268.677 & 9.268 & .000 \\
Intercept & 57154.165 & 1 & 57154.165 & 417.545 & .000 \\
Cognitive Styles & 5374.901 & 2 & 2687.450 & 19.633 & .000 \\
Gender & 679.537 & 1 & 679.537 & 4.964 & .030 \\
Cognitive styles* Gender & 755.629 & 2 & 377.814 & 2.760 & .072 \\
Error & 7254.717 & 53 & 136.881 & & \\
Total & 159403.000 & 59 & & & \\
Corrected Total & 13598.102 & 58 & & & \\
\hline
\end{tabular}

A. R Squared $=.466$ (Adjusted R Squared $=.416)$

According to Table II, the significant level reported by the computer for the effect of cognitive styles is .000 . Therefore, it can be concluded that the differences between the means of the different cognitive styles were significant at 0.05 and 0.01 levels. Besides, gender differences were significant at 0.05 levels. Additionally, the interaction between the independent variables which was shown in the output as Cognitive styles* Gender was not significant. In other words, the results indicated that the two independent variables (field dependence/independence and gender differences), with no interaction between them, have an effect on the dependent variable (vocabulary knowledge). As such, in order to determine where the effect lies exactly, a Scheffé test was carried out. The results are shown in Table III. 
TABLE III.

DIFFERENCES IN COGNITIVE STYLES AMONG THE THREE GROUPS MULTIPLE COMPARISONS (SCHEFFE) ON COGNITIVE STYLES

\begin{tabular}{lllllll}
\hline & & & & \multicolumn{3}{c}{$95 \%$ Confidence Interval } \\
\hline (I) FD/FI & (J) FD/FI & Mean Difference (I-J) & Std. Error & Sig. & Lower Bound & Upper Bound \\
FD & MID & -16.70 & 7.084 & .071 & -34.54 & 1.14 \\
& FI & $-18.67 *$ & 3.135 & .000 & -26.57 & -10.78 \\
MID & FD & 16.70 & 7.084 & .071 & -1.14 & 34.54 \\
& FI & -1.97 & 7.134 & .962 & -19.94 & 15.99 \\
FI & FD & $18.67^{*}$ & 3.135 & .000 & 10.78 & 26.57 \\
& MID & 1.97 & 7.134 & .962 & -15.99 & 19.94 \\
\hline
\end{tabular}

*The mean difference is significant at the 0.05 level

As was shown in Table III, the mean difference in field dependents and field independents was significant. In this regard, there was a difference between field dependents and their counterparts, field independents. Also, as it is obvious, the gender makes a difference. Therefore, it can be stated that the first hypothesis of the study, which assumed that field dependence/independence cognitive styles do not influence the EFL learners' lexical knowledge was rejected. Moreover, the findings supported the second hypothesis, which stated that interaction of gender does not affect the learners' knowledge of vocabulary.

The results of this study supported the evidence that males and females learn differently from each other (Grebb, 1999; Ebel, 1999; Cavanaugh, 2002). Furthermore, the findings are in conflict with what was carried out in this area by Yang (2006), who has found that learning styles are not the effective factors affecting learners' achievements, and maintains that the field-independent individuals do not differ significantly from their counterparts, field-dependent individuals.

\section{CONCLUSION}

As individuals with different cognitive styles and gender might have different performance outcome in language learning, evaluating learners with regard to these learning characteristics and differentiating between them in reference to their lexical knowledge would lead to a more reliable assessment of their competence and consequently could result in more effective language teaching strategies and learning. In this regard, findings of this research could be interpreted as being supportive of the idea that the field-dependent/independent cognitive styles and gender differences could be considered as effective factors influencing the learners' knowledge of vocabulary in the field of second or foreign language acquisition. Nevertheless, there was no probable interaction between the students' cognitive styles of field dependence/independence and male or female regarding their vocabulary knowledge. Therefore, with regard to the obtained results and findings, understanding the effective role of students' cognitive aspects and gender will enable teachers and researchers to design appropriate materials and activities to help students enhance their lexical competence.

\section{ACKNOWLEDGEMENT}

This research would not have been conducted without the help of several individuals who in one way or another extended their valuable assistance in the preparation and completion of this study. First and foremost, we are very grateful to Dr. Abdollah Keshavarzi, Shiraz Azad University Professor, for his cooperation in the administration of the tests and giving us the valuable time of his classes.

\section{REFERENCES}

[1] Beck, I.L., McKeown, M.G., \& Kucan, L. (2002). Bringing words to life: Robust vocabulary instruction. New York: Guilford Press.

[2] Bialystok, E. (1981). The role of conscious strategies in second language proficiency. The Modern Language Journal, 65 (1), 24-35.

[3] Bialystok, E. (1992). Attentional control in children's metalinguistic performance and measure of field Independence. Developmental Psychology, 28 (4), 654-664.

[4] Bialystok, E., \& Fröhlich, M. (1978). Variables of classroom achievement in second language learning. The Modern Language Journal, 62 (7), 327-336.

[5] Birckbichler, D., \& Omaggio, A. (1978). Diagnosing and responding to individual learner needs. The Modern Language Journal, 62 (7), 327-336.

[6] Brodkey, D., \& Shore, H. (1976). Student personality and success in an English language program. Language Learning, 26 (1), 153-162.

[7] Brown, H.D. (1987). Principles and practices in second language teaching and learning. Rowley, Mass: Prentice Hall.

[8] Brown, H. D. (1994). Principles of language learning and teaching (3rd Ed.). San Francisco: Prentice Hall.

[9] Busch, D. (1982). Introversion-Extraversion and the ESL proficiency of Japanese students. Language Learning, 32 (1), 109132.

[10] Carter, E.F. (1988). The relationship of field dependent-independent cognitive style to Spanish language achievement and proficiency: A preliminary report. Modern Language Journal, 72, 21-30.

[11] Cavanaugh, D. (2002). Hemispheric preference. New York: Cambridge University Press. 
[12] Chapelle, C., \& Roberts, C. (1986). Field independence and ambiguity tolerance as predictors of proficiency in English as a second language. Language Learning, 36(1), 27-46.

[13] Chastain, K. (1975). Affective and ability factors in second language acquisition. Language Learning, 25 (1), 153-161.

[14] Drane, M., Halpin, G., Halpin, W.G., von Eschenbach, J., \& Worden, T. (1989). Relationships between reading proficiency and field dependence/independence and sex. Education Research Quarterly, 13(2), 2-10.

[15] Dreyer, C., \& Vander Walt, J. L. (1994). The significance of learner variables as predictors of ESL proficiency. Studia Anglica Posnaniensia, XXIX, 91-103.

[16] Ebel, R. (1999). Encyclopaedia of Educational Research. Toronto: Engros

[17] Eftekhar Hosseini, Z. (2005). The effect of field dependent/independent cognitive style on the choice of vocabulary learning strategies used by Iranian EFL university students. Unpublished M.A dissertation, Islamic Azad University, Shiraz, Iran.

[18] Forns-Santacana, M., Amador-Campos, J.A., \& Roig-Lopez, F. (1993). Differences in field dependence/independence cognitive style as a function of a socioeconomic status, sex, and cognitive competence. Psychology in the schools, 30 (2), 176186.

[19] Gardner, R.C., \& Lambert, W.E. (1972). Attitudes and motivation in second language learning. Rowley, Mass: Newbury House.

[20] Gardner, R.C., \& Smythe, P.C. (1975). Motivation and second language acquisition. The Canadian Modern Language Review, 21 (2), 218-230.

[21] Gardner, R.C., Smythe, P.C., \& Brunet, G.R. (1977). Intensive second language study: Effects on attitudes, motivation and French achievement. Language Learning, 27 (2), 243-261.

[22] Genesee, F., \& Hamayam, E. (1980). Individual differences in second language learning. Applied Psycholinguistics, 1, 95-110.

[23] Greb, E. (1999). Learning-style preferences of fifth through twelfth grade students medically diagnosed with attention deficit hyperactivity disorder. Ph.D. diss., St. John's University.

[24] Guiora, A.Z., Paluszny, M., Beit-Hallahmi, B., Catford, J.C., Cooley, R.E., \& Dull, C.Y. (1975). Language and person studies in language behavior. Language Learning, 25 (1), 43-61.

[25] Hansen-Strain, L. (1984). Field dependence-independence and language testing: Evidence from six Pacific island cultures. TESOL Quarterly, 18, 311-324.

[26] Hansen, J., \& Stansfield, C. (1981). The relationship of field dependence/independence cognitive styles and foreign language achievement. Language Learning, 31(2), 349-367.

[27] Hansen, J., \& Stansfield, C. (1982). Student-teacher cognitive styles and foreign language achievement: A preliminary study. The Modern Language Journal, 66 (2), 263-273.

[28] Hosenfeld, C. (1979). A learning-teaching view of second language instruction. Foreign Language Annals, 12 (1), 51-57.

[29] Hwang, W. (1997). Field-independence and English language listening comprehension of Taiwanese university students. Unpublished Ph. D dissertation, University of Kansas.

[30] Kraft, C. \& Nichel, B. (1995). Review Essay: Perspectives on Languages and Communications. Journal of Women in Culture and Society, 3, p. 638-651.

[31] Mrosla, H. P. (1983). Difference between field-dependence / field-independence cognitive styles of low and high achievement mathematics students. Ph. D Thesis. Denton, TX: University of North Texas.

[32] Nation, I.S.P. (2007). Vocabulary size test (monolingual version). Victoria University of Wellington. Retrieved February, 24, 2010, from http://www.victoria.ac.nz/lals/staff/paul-nation.aspx.

[33] O’Malley, M.J., \& Chamot, A. U. (1990). Learning strategies in second language acquisition. Cambridge: Cambridge University Press.

[34] O’Malley, M.J., Chamot, A. U., Stewner-Manzanares, G., Kupper, L., \& Russo, R. (1985a). Learning strategies used by beginning and intermediate ESL students. Language Learning, 35 (1), 21-46.

[35] O’Malley, M.J., Chamot, A. U., Stewner-Manzanares, G., Kupper, L., \& Russo, R. (1985b). Learning strategy applications of students of English as a second language. TESOL Quarterly, 19 (4), 557-584.

[36] Oxford, R.L. (1989). Use of language learning strategies: A synthesis of studies with implications for strategy training. System, $17(2), 235-247$.

[37] Oxford, R.L. (1990). Language learning strategies: What every teacher should know. New York: Harper Collins.

[38] Padilla-Falto, O. (1996). The effects of formal instruction and field dependence on the acquisition of the Spanish prepositions por and para. Ph. D Thesis. University of Georgetown.

[39] Read, J. (2002). Vocabulary and testing. Vocabulary: Description, acquisition and pedagogy. Cambridge: Cambridge University Press.

[40] Reid, J.M. (1987). The learning style preferences of ESL students. TESOL Quarterly, 21 (2), 87-111.

[41] Rezaee, M., \& Farahian, M. (2012). The case study of a field-independent English language learner. Journal of Social and Behavioral Sciences, 47, 114-119.

[42] Rezaeian, M. (2012). An investigation into the relationship between field dependence/independence, sex, and age, towards EFL proficiency in Iranian language learners. The Iranian EFL Journal, 8 (5), 82 -98.

[43] Roever, C. (2001). A web-based test of interlanguage pragmatic knowledge. Unpublished doctoral dissertation, University of Hawaii, Hawaii.

[44] Rostampour, M., \& Niroomand, S.M. (2014). Field dependence/independence cognitive styles: Are they significant at different levels of vocabulary knowledge? International Journal of Education and Literacy Studies, 2 (1), 52-57.

[45] Saurenman, D. (1980). Differential placement of high achieving and low achieving gifted pupils in grades four, five, and six on measures of field dependence/independence, creativity, and self-concept. Gifted Child Quarterly, 24 (2), 81-86.

[46] Saville-Troike, M. (2006). Introducing second language acquisition. Cambridge: Cambridge University Press.

[47] Seal, B.D. (1991). Vocabulary learning and teaching. In M. Celce-Murcia (Eds.), Teaching English as a foreign language. Boston. Heilne and Heiline.

[48] Şener, S. (2009). The Relationship between Vocabulary Learning Strategies and Vocabulary Size of Turkish EFL Students. Retrieved from http://yadem.comu.edu.tr/3rdELTKonf/spkr_sabriye_sener.htm on May 11th, 2012. 
[49] Skehan, P. (1991). Individual differences in second language learning. Studies in Second Language Acquisition, 13 (2), $275-$ 298.

[50] Tinajero, C., \& Paramo, M.F. (1998). Field dependence/independence and strategic learning. International journal of Educational Research, 29, 251-262.

[51] Wenden, A. (1983). Literature review: The process of intervention. Language Learning, 33 (1), 103-121.

[52] Wenden, A. (1986a). Helping language learners think about learning. English Language Teaching Journal, 40 (1), 3-12.

[53] Wenden, A. (1986b). What do second language learners know about their learning? A second look at retrospective accounts. Applied Linguistics, 7 (2), 186-205.

[54] Wenden, A., \& Rubin, J. (1987). Learner strategies in language learning. Englewood Cliffs, NY: Prentice-Hall.

[55] Witkin, H. A. \& Goodenough, D. R. (1981). Cognitive styles: Essence and origins. New York: International Universities Press.

[56] Witkin, H.A., Moore, C.A., Goodenough, D.R., \& Cox, P.W. (1977). Field-dependent and field-independent cognitive styles and their educational implications. Review of Educational Research, 47 (1), 1-64.

[57] Witkin, H.A., Moore, C.A., Oltman, P.K., Goodenough, D.R., Friedman, F., Owen, D.R., \& Raskin, E. (1977). Role of the field-dependent and field-independent cognitive styles in academic evolution: A longitudinal study. Journal of Educational Psychology, 69(3), 197-211.

[58] Witkin, H. A., Raskin E., Oltman, P. K., \& Karp, S. A. (1971). A manual for the Group Embedded Figures Test. Palo Alto, CA: Consulting Psychologists Press.

[59] Yang, R. (2006). The relationship between learning styles and L2 learning. Sino-US English Teaching, 3(9), 25-28.

Seyyedeh Mitra Niroomand is an M.A holder of TEFL from Islamic Azad University, Abadeh Branch, Abadeh, Iran. She has been teaching English at different English language institutes for more than ten years. The courses she has taught ranges from elementary courses to advanced levels, including FCE, IELTS, and TOEFL. She has already published some papers, article and book reviews at international language journals. Her research areas of interest include applied linguistics, psycholinguistics, motivation and autonomy in EFL learning, and dynamic assessment in language testing.

Mohammad Rostampour is a faculty member at Islamic Azad University, Abadeh Branch, Abadeh, Iran. He got his B.A in English Language and Literature, then M.A and PhD in TEFL. He has been teaching English for more than twenty years. He has presented and published some papers on different areas of language at international conferences and language journals. His main areas of interest are language teaching methods, discourse analysis, and dialects. 